\title{
TOWARDS AN EFFECTIVE KENYAN LABOUR DISPUTE RESOLUTION SYSTEM: A COMPARISON WITH THE SOUTH AFRICAN LABOUR DISPUTE RESOLUTION SYSTEM ${ }^{1}$
}

\author{
Johana K Gathongo \\ LLB LLM LLD \\ Nelson Mandela University \\ Adriaan van der Walt \\ BJuris BA(Hons) $L L B$ \\ Professor, Mercantile Law \\ Nelson Mandela University
}

SUMMARY

There have been notable concerns in the current dual dispute resolution system in Kenya. The problems include protracted referral timeframes for dismissal disputes, non-regulation of maximum timeframes for the agreed extension after 30 days conciliation period has lapsed, the absence of statutory timeframes for appointing a conciliator/ commissioner and arbitration process under both the Labour Relations Act, 2007 and the Employment Act, 2007. Likewise, the responsibility of resolving statutory labour disputes in Kenya is still heavily under the control of the government through the Ministry of Labour. There is still no independent statutory dispute resolution institution as envisaged by the Labour Relations Act, 2007. As a result, the Kenyan dispute resolution system has been criticised for lack of impartiality leading to the increase in strikes and lockouts.

This article examines the effectiveness of the Kenyan labour dispute resolution system. The article evaluates the provisions of international labour standards relevant to labour dispute resolution. The article illuminates and describes the bottlenecks in the current Kenyan system and argues that it does not adequately respond to the needs of parties in terms of the international labour conventions. A comparative approach with South Africa is adopted to see how independent institutions, such as the Commission for Conciliation, Mediation and Arbitration, Bargaining Councils and specialised Labour Courts can lead to effective dispute resolution. In view of that a wide range of remedial intervention intended to address the gaps and flaws highlighted in the study are made. Systematically, the article provides suggestions and possible solutions for a better institutional framework and processes to address them.

This article is based on an LLD thesis entitled: Labour Dispute Resolution in Kenya

Compliance with International Standards and a Comparison with South Africa. 


\section{$1 \quad$ INTRODUCTION}

Employment disputes are a constant feature in employment relationships. In spite of all the good intentions to prevent them from arising, it is unlikely that the status quo will change in the foreseeable future. ${ }^{2}$ This inevitable situation arises primarily due to the simultaneous existence of both mutual and opposing interests in employment relations. A challenge, therefore, is to see disputes not only as inevitable ${ }^{3}$ but also as a potential opportunity to work out the differences as well as a possibility of re-balancing the relationship in order to find common ground and strengthen relationships. To realise this, both parties must come to the negotiation table as like-minded, equal status and amenable in their effort to resolve their disputes. However, in practice, that is not always the case. The inconvenient but inescapable truth of the inequality of power between employee and employer in the employment relationship dictates the ineffective dispute resolution strategies. In addition, if this happens, many disputes capable of early resolution escalate into the external dispute resolution institutions.

It has to be stressed at the outset that labour disputes are highly emotive issues to both the employer and the employee alike. ${ }^{4}$ Therefore, the manner in which one chooses to resolve a dispute is crucial as it could either escalate the tension or subdue it. ${ }^{5}$ In the workplace, it is crucial that any reasonable attempts through a policy framework such as grievance and disciplinary procedures designed to deal with disputes must be effective. This is critical for the sake of maintaining and fostering healthy long-term employment relationships. ${ }^{6}$ For trade unions, an effective dispute resolution

2 Talvik Best Practices in Resolving Employment Disputes in International Organizations, Paper presented at Conference Proceedings ILO Geneva (September 2014) i. S 1 of the 2007 LRA of Kenya (hereinafter "the 2007 LRA") defines "trade dispute" to mean: "a dispute or difference, or an apprehended dispute or difference, between employers and employees, between employers and trade unions, or between an employers' organisation and employees or trade unions, concerning any employment matter, and includes disputes regarding the dismissal, suspension or redundancy of employees, allocation of work or the recognition of a trade union." In Kenya, the term "trade dispute" is used in reference to labour or employment disputes. In terms of s213 of the Labour Relations Act 66 of 1995 (hereinafter "the 1995 LRA"), a "dispute" is defined to mean nothing more than to "include an alleged dispute".

3 ILO Labour Dispute Systems: Guidelines for Improved performance (2013) ii. See also Ury, Brett and Goldberg "Three Approaches to Resolving Disputes: Interests, Rights and Power" in Lewicki, Barry and Saunder (eds) Negotiation: Readings, Exercises and Cases (2007) 56 .

4 Generally, any study of dispute resolution hinges on a proper and thorough understanding of the concept of conflict and dispute. These two concepts differ conspicuously. Whereas a dispute is regarded as a short-term disagreement that can result in the disputants reaching some sort of resolution, conflict, in contrast, is long-term with deeply rooted issues that are seen as "non-negotiable of which dispute forms part of it". In fact, conflict can exist without a dispute, but a dispute cannot exist without a conflict. Costintino and Merchant Designing Conflict Management Systems: A Guide to Creating Productive and Healthy Organizations (1996) 4-5.

5 Bendix Industrial Relations in South Africa (2010) 132. See also Animashaun, Odeku and Nevondwe "Impact and Issues of Alternative Dispute Resolution in South Africa with Emphasis on Workplace Dispute" 201416 Mediterranean Journal of Social Sciences 678.

6 Buckley Employment Cases on the Rise (2009) 56. See also Blapin Comparative Labour Law and Industrial Relations (2005) 89; Consensus Seeking Skills for Third Parties Training Package (International Labour Organization 1997); Gakeri "Placing Kenya on the Global 
mechanism remains a key component since it plays a major role in the achievement of their objectives. It is argued that a good dispute procedure attacks problems as they arise, whereas an effective dispute procedure anticipates them and prevents them from occurring. ${ }^{7}$ In the same way, this article adds that a dispute resolution process is considered appropriate where its procedures, goals and values suit the requirements of the parties to the dispute.

\section{REASONS FOR CHOOSING SOUTH AFRICA AS A BENCHMARK FOR THIS ARTICLE}

The purposes of comparative research are many, but one key task is to support and contribute to theory as well as the practical formation of an existing system. ${ }^{8}$ This article undertakes a comparative study with South Africa for various important reasons. Firstly, like Kenya, South African law has most of its roots emanating from the English law due to the British colonisation that took place around the $18^{\text {th }}$ century. ${ }^{9}$ Its marked influence prevails in both countries private and public sectors. Also, the South African jurisprudence of labour dispute resolution is older than that of Kenya, making its experience worth comparing with Kenya's less developed. As a result, Kenya can draw specific and general lessons from the South African model in order to address and improve the effectiveness of its labour dispute resolution system and framework. This article acknowledges, however, that there are distinct differences in areas such as economic development in both countries. Nonetheless, this article argues that the differences between the two systems do not mean that Kenya cannot adopt solutions that have proved and marked with success in South Africa in order to address the challenges experienced in the Kenyan system. Therefore, a degree of

Platform: An Evaluation of the Legal Framework on Arbitration and ADR" 20111 International Journal of Humanities and Social Science 219; South "What's Driving the Interest in Mediation Globally: Lessons from Recent Experiences" 2008 IBA Mediation Committee Newsletter 1; Muigua Avoiding Litigation through the Employment of ADR, InHouse Legal Counsel, Marcus Evans Conference: Tribe Village Market Hotel, Kenya (8-9 March 2012); Muigua and Francis ADR Access to Justice and Development in Kenya 2 and also Kajimanga Enhancing Access to Justice through ADR mechanisms - The Zambian Experience, Annual Regional Conference, Southern Sun, May fair, Nairobi Kenya (25-26 July 2013) 9; Cyprus High-Level Tripartite Seminar on the Settlement of Labour Disputes through Mediation, Conciliation and Arbitration and Labour Courts (18th-19th October 2007) 1; Buckley Employment Cases on the Rise 56; Benjamin Assessing South Africa's CCMA 2013 (iii). International Training Centre of the ILO, Labour Dispute Systems, Guideline for Improved Performance, 2013.

7 Thuo Distance Learning Material, School of Business Kenya Methodist University 52 Cases-are-on-the-climb\&catid=34:legal-resources\&ltemid=56 http://online.kemu.ac.ke/dlm/ images/campus/sbe/300/HRMG\%20333-Employee\%20Relations.pdf.

8 Michael, Lewis-Beck, Bryman and Liao Comparative Research in the SAGE Encyclopedia of Social Science Research Methods $2004 \mathrm{http}: / /$ methods.sagepub.com/reference/thesage-encyclopedia-of-social-science-research-methods/n141.xml. (accessed 2017-01-12) 3.

9 Kamau An Insight into the History of Labour Law in Kenya (2014) 1; see also ILO National Labour Law Profile: Kenya-Historical Background http://www.ilo.org/ifpdial/informationresources/national-labour-law-profiles/WCMS_158910/lang--en/index.htm (accessed 201603-16). 
transferability can be accepted. ${ }^{10}$ Although every labour dispute resolution system is tailor-made for the country in which it is meant to be used and while it may be true that one size does not fit all, there are certain aspects of labour dispute resolution, which are universally present and vital in all countries' labour dispute resolution systems.

It is important to realise that, it is not the intention of this article to evaluate and rank the effectiveness of the system in both countries. Neither does this article attempt to suggest a perfect framework for an effective labour dispute resolution. The focus of this article is to contribute towards a better and more effective dispute resolution as envisaged by the 2007 LRA and the Employment Act, 2007.

Against this background, a dualistic approach involving a theoretical analysis of both the law and practices of each country is undertaken. This includes an investigation into the effectiveness of the current statutory labour dispute resolution system contained in the 2007 LRA and the 2007 Employment Act. It highlights some of the problems, gaps and inherent deficiencies incorporated in the aforesaid Act's dispute resolution framework.

\section{HISTORICAL DEVELOPMENTS OF LABOUR RELATIONS IN SOUTH AFRICA AND KENYA}

\section{South Africa}

South Africa went through a remarkable history in its labour laws and labour relations from the early $19^{\text {th }}$ century to the present day in a quest to regulate and level the playing ground for labour relations. Before 1924, a lot had emerged which was not without effects on the later labour dispute resolution in the workplace. During this period, the South African economy was largely agrarian, with agriculture as the main activity. ${ }^{11}$ Various Master and Servants Acts, including the Master and Servant Act of 1856, governed the employment relationship. ${ }^{12}$ The discovery of gold and diamond led to an influx of labour and workers in the mines. This eventually culminated in the formation of South Africa's first trade union, the Carpenters' and Joiners' Union in 1881. Subsequently, the contemporary global economy, as well as dynamic resistance against violation of human rights, resulted in most countries reviewing their labour dispute resolution system. ${ }^{13}$ However, the

10 Musukubili Towards an Efficient Namibian Labour Dispute Resolution System: Compliance with International Labour Standards and a comparison with the South African System (2013) 300.

11 Hall and Ben Commercial Farming and Agribusiness in South Africa and their changing roles in Africa's Agro-food System, South Africa International Conference Rural Transformations and Food Systems, University of the Western Cape, (April 2015) 20-21.

12 Bergh "White farmers and African Labourers in the Pre-industrial Transvaal" 201055 Historia 20; Swiegers Britain and the Labour Question in South Africa: The Interaction of State, Capital, Labour and Colonial Power 1867-1910 (Unpublished Doctoral thesis, University of the Free State 2014) 101-108; SAHO “The Struggle against Sweating" (2010) 1.

13 Van Jaarsveld and Van Eck Principles of Labour Law (1998) 67. 
existing state of affairs in South Africa was intensified by the ill-fated history of apartheid. ${ }^{14}$

Historically, the Industrial Relations $\mathrm{Act}^{15}$ was the first statute that created the dispute resolution system in South Africa. The mere fact that it excluded blacks from its application is an indication clear enough to realise its ineffectiveness. ${ }^{16}$ Besides, it was established to deal primarily with disputes of interest. ${ }^{17}$ In due course, the aforementioned Act was amended to create arbitration for job reservation disputes. ${ }^{18}$ As things stood, when the new democratic era was ushered in, labour legislation did not provide for adequate mechanisms to deal with collective and individual relationships. ${ }^{19}$ For that reason, there was an inevitable need to overhaul the entire labour law administration that existed during the apartheid era. ${ }^{20}$ The Industrial Relations Act of 1922 was repealed and replaced by the Labour Relations Act of $1956 .{ }^{21}$ Aside from including black people in its application, the aforementioned Act established the industrial courts, which operated in a complex and unsystematic manner. ${ }^{22}$ Ultimately, at the dawn of the new democratic in 1994, South Africa underwent a series of changes to free itself of the apartheid laws and enact new laws in line with the Constitution of the Republic of South Africa, 1996. Of particular importance to this article was the enactment of the 1995 LRA. One of the founding principles of the 1995 LRA was the creation of mechanisms that would enable speedy and effective resolution of disputes. ${ }^{23}$ Accordingly, the 1995 LRA introduced the Commission for Conciliation, Mediation and Arbitration (CCMA) together with a specialised system of Labour Courts to replace the former Conciliation Boards and Industrial Court. On the other hand, the Constitution created the Supreme Court of Appeal and the Constitutional Court. ${ }^{24}$

\section{Kenya}

In Kenya, the United Kingdom established its influence in the 19th century. In 1895, Kenya became a British Protectorate, and the highlands were opened to white settlers. The history can be traced as far back as 1895 until just before independence in 1963. By virtue of this, many principles of the British labour law featured prominently in the Kenyan labour statutes.

14 Mphahlele Labour Relations Disputes Resolutions System: Is it Effective? (Unpublished Mini Masters Dissertation, University of Pretoria 2016) 11.

15 Act 11 of 1924.

16 S 24 defined an employee in such a way so as to exclude pass-bearing African workers from the definition. Therefore, black people were precluded from registered trade unions and only registered trade unions could take part in the statutory collective bargaining system.

17 Bhorat "Understanding the Efficiency and Effectiveness of the Dispute Resolution System in South Africa: An analysis of CCMA Data" 2007 University of Cape Town, Development Policy Research Unit (DPRU).

18 Ibid.

19 Explanatory Memorandum (1995)16 ILJ 282.

20 Explanatory Memorandum (1995)16 ILJ 278.

21 Hereinafter "the 1956 LRA".

22 Explanatory Memorandum (1995)16 ILJ 285.

$23 \mathrm{~S} 1$ (d)(iv) of the 1995 LRA.

24 See fn 16 above 51. 
Following the European "Scramble for Africa", the British moved into Kenya, occupied the most fertile land and forced the Kenyans off the land. Cunningly, the main characteristics of the incursion of the colonial masters were the introduction of labour laws and policies that appeared largely designed to facilitate the economic and commercial objectives and interests of the colonial masters. ${ }^{25}$ It was at this time that the colonial government felt the need to pass labour legislation that would marginalise Kenyans in order to protect their own interests, and in particular labour engagements. The result was the passing of the Master and Servant Act of 1906, which ensured that a cost system of all white people as masters and all Africans as servants was strongly enforced. This Act was first added to the Statute Book of the East Africa Protectorate in 1906 and was to remain the most important element of Kenya's labour laws until the 1950s.

By the mid- $19^{\text {th }}$ Century, the Master and Servant laws had extended throughout the British Empire, connecting workers in South Africa in a common system for the regulation of labour. ${ }^{26}$ For the most part, the framework of the Master and Servant Act was clearly designed in such a way that only a few white people would benefit. In fact, a lot of the measures employed by the British settlers in Kenya were imported from South Africa and Southern Rhodesia (Zimbabwe). ${ }^{27}$ Its primary aim, however, was to secure a cheap labour supply to service the emerging enterprise in agriculture and to secure complete control over Africans. With Kenya attaining independence on December 12, 1963, and the subsequent establishment of an Industrial Court in 1964, a strong foundation was laid for the development of an approachable dispute resolution system in Kenya, particularly through the use of ADR methods. From this point, numerous negotiations and consultations took place leading up to the passing of the Trade Disputes Act in $1965 .{ }^{28}$ This legislation sets out the basis for which labour disputes were to be resolved. From 1965 onwards, parliament enacted several labour laws and more and more trade unions were formed and recognised by the government. ${ }^{29}$ However, these laws were criticised for failing to live up to their intended purposes. The system was pitted with problems, which created unnecessary hurdles to the realisation of a fast, effective and efficient dispute resolution and more often than not, was unsatisfactory to the parties involved. ${ }^{30}$ They did little to change the

25 Ocobock "Earning an Age: Migration and Maturity in Colonial Kenya" 1895-1952 44 African Economic History 4472.

26 For the use of Master and Servant enactments in nineteenth-century England, see Simon "Master and Servant" in Saville (ed) Democracy and the Labour Movement (1954). For examples of the transplanting of the codes to the British colonies, see Colin "The Abolition of the Masters and Servants Act" 1975 South African Labour Bulletin 3746.

27 Global Black History "Forgotten History: Colonization of Kenya" 7 July 2015 1888-1920" http://www.globalblackhistory.com/2015/01/forgotten-history-colonization-of-kenya-18881920.html (accessed 2016-07-31).

28 The Trade Disputes Act, Cap 234. This Act was later repealed by the 2007 LRA.

29 This legislation included The Employment Act (Cap.226), The Regulation of Wages and Conditions of Employment Act (Cap. 229), The Trade Unions Act (Cap. 233), The Trade Disputes Act (Cap. 234), The Workmen's Compensation Act (Cap. 236), The Factories Act (Cap. 514).

30 George Njau Maichibu v Mungai Maichibu and Joseph Kimani Waithima (2007) eKLR, the suit was filed in 1981 but concluded more than 25 years later in 2008. Also, in contrast to the open-ended time the ministry had to conciliate a dispute, the new law obliges the 
restrictive legislative framework that existed prior to independence. Consequently, some of the trade unionists started expressing their frustrations. Substantially, part of the contention was that the enacted laws did not address the restrictive labour rights. ${ }^{31}$ The continued uneasiness led to intense deliberations on the future of a labour dispute resolution system and the reassessment of the structure and procedures in the Trade Dispute Act.

In 2001, the Attorney General appointed a task team to undertake a comprehensive review of the Kenyan labour legislation and develop national labour laws within the project of the ILO. ${ }^{32}$ Among other reasons, the review was to ensure that the labour legislation was responsive to contemporary economic and social changes. Similarly, the task team was to establish a system of ADR mechanisms that contrasted starkly with the preceding ones by ushering in perhaps a more sophisticated process of labour dispute resolution and prevention. ${ }^{33}$ The product of the review was the enactment of five major pieces of legislation. These are the Labour Relations Act, 2007; the Employment Act, 2007; the Labour Institutions Act, 2007; the Work Injury Benefits Act, 2007 and The Occupational Safety and Health Act, 2007.

Currently, the 2007 LRA and the 2007 Employment Act are the primary legislation regulating collective and individual labour dispute resolution respectively. In view of the above, the article seeks to establish and explore the different mechanisms, which both of the aforementioned legislation provide for in assisting parties in the peaceful resolution of disputes in the workplace in Kenya. Of particular importance to this article is to examine the effectiveness of the statutory labour dispute resolution. This is done through a critical comparative analysis of the current statutory framework and mechanisms entrusted to fulfil the labour dispute resolution mandate.

ministry to take concrete action to resolve a dispute within 30 days of receiving the notice of a dispute. See also Fashoyin Collective Bargaining and Employment Relations in Kenya, Working Paper, Industrial and Employment Relations Department International Labour Office, Geneva (October 2010) 13.

31 Mulama "Rights-Kenya: Colonial Labour Laws Violate ILO Conventions" 2007 Inter Press Service 1.

32 The task team comprised representatives of Workers (COTU), Employers (FKE), the Government and experts in various fields. The task team was to comprehensively review and amend or repeal the following six (6) core labour statutes: The Employment Act, Cap 226; The Regulation of Wages and Conditions of Employment Act, Cap 229; The Trade Unions Act, Cap 233; The Trade Disputes Act, Cap 234; The Factories and Other Places of Work Act, Cap 514; and The Workmen's Compensation Act, Cap 236. Kenya joined the ILO in 1949. As of 4 June 2004, it had ratified 49 ILO Conventions of which 43 were in force in the country http://www.ilo.org/ifpdial/information-resources/national-labour-law-profiles/ WCMS_158910/lang--en/index.htm (accessed 2015-05-28). See also http://www.lo.org/ dyn/normlex/en/f?p=1000:11110:0::NO:11110:P11110_COUNTRY_ID:103315 and http:// www.ilo.org/dyn/normlex/en/f?p=1000:11200:0::NO:11200:P11200_COUNTRY ID:103315.

33 S 62-72 of the 2007 LRA. 


\section{4 KENYAN STATUTORY LABOUR
RISPUTE
RESOLUTION SYSTEM: ANALYSIS OF THE
FRAMEWORK, MECHANISMS AND THEIR
EFFECTIVENESS}

Ever since 2007, the 2007 LRA and the 2007 Employment Act mainly regulate the statutory labour dispute resolution in Kenya. Both legislations seek to remedy the problems that existed in the Trade Dispute Act. One of the primary purposes of the 2007 LRA is to introduce an efficient, costeffective, accessible and expeditious dispute resolution system. ${ }^{34}$ This gives effect to Article 159 of the Constitution. ${ }^{35}$ A cursory look at Article 159 is that it is phrased in peremptory terms. This means that in exercising judicial authority, the courts and tribunals must take into account the fundamental principles of alternative forms of dispute resolution, including reconciliation, mediation, arbitration and traditional dispute resolution mechanisms. ${ }^{36}$

Looking back, it is a decade now since the labour dispute resolution system under the 2007 LRA and the 2007 Employment Act were enacted. Despite what appeared initially to be a generally favourable dispute resolution system with the capacity to prevent or reduce disputes, the literature suggests that there has only been a change of emphasis from the previous repealed labour laws to the system under both the 2007 LRA and the 2007 Employment Act. ${ }^{37}$ The shortcomings of the previous legislation may have been duplicated and perhaps new ones additionally integrated especially regarding the framework and processes for labour dispute resolution. Incidentally, the Federation of Kenyan Employers has come out voicing their frustration by arguing that the current framework of the labour laws is constantly frustrating Kenyan employers since they continue grappling with the negative effects of implementing the regulations. ${ }^{38}$ Similarly, they acknowledge that while the intention of the labour laws was noble, they are less likely to enhance the relationship between the employers and employees. They contend that employees are favoured while

34 The Preamble of the 2007 LRA declares one of its purposes as "the encouragement of effective collective bargaining and promotion of orderly and expeditious dispute settlement, conducive to social justice and economic development and for connected purposes."

35 The Constitution of the Republic of Kenya, 2010 (hereinafter "the Kenyan Constitution").

36 Article 159(2)(c) of the Constitution of Kenya, 2010 states such principles shall be promoted as long as they do not contravene the Bill of Rights, are not repugnant to justice and morality or result in outcomes that are repugnant to justice or morality and are not inconsistent with the constitution or any written law. See also a discussion by Muigua Alternative Dispute Resolution and Article 159 of the Constitution: In Legal Resource Foundation Trust, Programme for Judges and Magistrates Training, Lake Baringo Soi Lodge, Kenya (7 September 2012) 9.

37 Most of the disputes relate to the collective bargaining process: failure to negotiate, issues in implementation, or violation of the Collective Bargaining Agreement (CBA). See also Fashoyin Working Paper Industrial and Employment Relations Department International Labour Office, Geneva 29.

38 Chepkuto, Kipsang and Chemirmir "Labour Laws and Regulatory Practices in Kenya: An Analysis of Trends and Dynamics" 20152 International Journal of Research in Management and Business Studies 39 40. See also Federation of Kenya Employers (F.K.E) and Central Organisation of Trade Unions (COTU) Labour Laws Reforms in Kenya 10ed (2008) 9. 
employers are not. This may cause acrimony between the two parties. ${ }^{39}$ In practice, evidence reveals that the labour dispute resolution system is currently under strain, as is evident from industrial actions experienced on a regular basis across different sectors in the country as well as long delays in the finalisation of disputes attributed to a failing system. ${ }^{40}$ It must be remembered that no matter how unavoidable employment disputes may be, they do not always need to end in costly and protracted litigation, the exchange of heated and sometimes defamatory briefs. ${ }^{41}$ Arguably, among the reasons associated with the situation in Kenya, seems to be the lack of proper and effective institutional and statutory mechanisms for labour dispute resolution that engage parties in meaningful bipartite dialogue.

Clear gaps between the statutory framework regulating the resolution of a labour dispute and the application of laws remain and continue to pose huge challenges. To some extent, this has slowed down the ultimate realisation of the primary purpose of an expeditious labour dispute resolution envisaged by the 2007 LRA $^{42}$ and the 2007 Employment Act. Given the historical context of the passage of these laws and ineffectiveness of the dispute resolution system therein, it is an opportune time to consider the extent to which these laws have or have not effectively improved the labour dispute resolution system in the country.

Besides, the problems mentioned above, other problems in practice that unduly hinder the effectiveness and efficiency of labour dispute resolution relate to the current structural and referral framework for routing labour disputes. Some of the prevalent bottlenecks are highlighted and addressed in the next section.

\section{Dual system of labour dispute resolution}

Analysis of the labour dispute resolution system in Kenya reveals that the system is based on the dual system, which still exists to date. On the one hand, the labour dispute resolution framework under the 2007 LRA is purely dedicated to resolving collective labour disputes. The task of resolving collective labour disputes remain the responsibility of conciliators or a

39 Ibid.

40 Notable examples include the recent teachers strike in 2015 that saw teachers down tools for more than 35 days over a dispute concerning a salary increase. Also the 2017 doctor's strike, which endured for more than 90 days. The medics rejected a 40 per cent pay raise offer by the government, demanding fulfilment of the 2013 collective bargaining agreement requiring a 300 per cent increase. In the process of the strike, the Employment and Labour Relations Court sentenced seven union officials to a one-month suspended jail term over the doctor's strike. The matter was further referred to the Court of Appeal where the court ordered the release of the officials. During the currency of the doctors' strike, lecturers and non-teaching staff in public universities also went on strike for more than 40 days, demanding a 400 per cent pay increase and thus deepening a crisis in public services as the country headed towards elections.

41 Talvik Paper presented at Conference Proceedings ILO Geneva v.

42 The Preamble of the 2007 LRA declares one of its purposes as "the encouragement of effective collective bargaining and promotion of orderly and expeditious dispute settlement, conducive to social justice and economic development and for connected purposes." 
conciliation committee appointed by the Cabinet Secretary. ${ }^{43}$ On the other hand, individual disputes are resolved in terms of the framework confined in the 2007 Employment Act. However, the Employment Act gives parties engaged in individual disputes an option of either referring their dispute to the Labour Officer or directly to the Employment and Labour Relations Court for resolution. ${ }^{44}$

It happens occasionally that the Cabinet Secretary or Labour Officer is also an interested party/parties in a dispute referred. This happens, for instance, to an employee who finds himself/herself in a labour dispute (e.g. an alleged unfair dismissal) against the government as his or her employer. The question that immediately springs to mind is to whom/where do such employees refer such labour disputes? This question consequently raises a number of problems that need substantiation. Perhaps with some exceptions and without underestimating the important role played by the Cabinet Secretary and the Labour Officer, serious criticism may be levelled against the current dual system of labour dispute resolution. Besides compromising the independence, such system undermines fairness, neutrality and impartiality that are at the core of any dispute resolution and therefore prejudicial to a party or parties in dispute. This happens since both the Cabinet Secretary and the Labour Officers are members of the executive arm of government and are at the same time deeply involved in the decision making of disputes. Besides, allowing them the liberty and control to facilitate adjudication on the same dispute they are party to is tragic and against the rules of natural justice especially nemo judex in causa sua ${ }^{45}$ and the audi alteram partem. ${ }^{46}$ This arrangement constitutes not only as a direct violation of Article 50 of the Constitution of Kenya that entrenches the right to a fair hearing, but also a breach of cardinal principles of the separation of powers. It also erodes impartiality and legitimacy, which are the key pillars in a conciliation process.

According to Mboh, the effectiveness does not only depend on the extent to which disputes can be resolved by the law but also, ease of access, simplicity, consistency, predictability and delivery of just outcomes to parties involved in labour disputes by the mechanisms in place. ${ }^{47}$ The earliest intervention and access to intervention in the form of conciliation, mediation and arbitration processes offers a good prospect of resolution as the

43 S 65 of the 2007 LRA. The Cabinet Secretary heads the Ministry of Labour, Social Security and Services. Currently, the structural and operational framework of the Ministry is founded on its Strategic Plan set forth in 2013-2017. The Ministry has several sub-divisions; key amongst them is the Public Relations Unit. The Public Relations Unit is further divided into four units among them the Legal Unit where labour disputes are referred for resolution.

44 S 47(1) and (3) of the 2007 Employment Act.

45 Nemo judex in causa sua (or nemo judex in sua causa) is a Latin phrase that means, literally, "no-one should be a judge in his own cause". It is a principle of natural justice that no person can judge a case in which they have an interest. The rule is very strictly applied to any appearance of a possible bias, even if there is actually none. Justice must not only be done, but must be seen to be done.

46 Audi alteram partem is a Latin phrase meaning "listen to the other side", or "let the other side be heard as well".

47 Mboh The Effectiveness of Dispute Resolution Mechanisms within the South African Labour Law System: A Critical Analysis (Unpublished Mini-Dissertation, North West University 2012) 41. 
experience of the CCMA has proven. It is not an accident that, following the dawn of democracy, South Africa took a giant step in releasing labour relations from state control by passing the Labour Relations Act ${ }^{48}$, which established the CCMA to promote statutory labour dispute resolution. ${ }^{49}$ Although sponsored by the government, the 1995 LRA expressly declares the CCMA as independent of any political party, trade union, employer or employers' organisation, a federation of trade unions or a federation of employers' organisation and has national jurisdiction. ${ }^{50}$ It is regarded as a pillar of the new dispensation. ${ }^{51}$ Besides enhancing the effective resolution of labour disputes, the CCMA was established in order to resolve disputes preferably expeditiously so as to avoid or mitigate the cost of protracted labour disputes. ${ }^{52}$ To date, the South African system is regarded as one of the most sophisticated labour dispute resolution systems in the world. ${ }^{53}$

The CCMA's constitutional mandate is drawn directly from section 23 of the Constitution of South Africa that deals with labour relations. The CCMA's mandate is drawn from the purpose of the 1995 LRA itself, which is "to advance economic development, social justice, labour peace and the democratisation of the workplace." ${ }^{54}$ The 1995 LRA identifies the mandatory functions that the CCMA is required to perform. ${ }^{55}$ The main functions of the CCMA are to attempt to conciliate any dispute that requires conciliation if there is no bargaining counsel having jurisdiction and to arbitrate any other matter that requires arbitration in terms of the aforesaid Act and conduct facilitation in operational requirement disputes. ${ }^{56}$ The explanatory

48 Act 66 of 1995. Hereinafter "the 1995 LRA".

49 The CCMA is governed by a Governing Body (Accounting Authority) appointed by the Minister of Labour (the Executive Authority), which in turn appoints the Director (Accounting Officer) of the CCMA. Governing Body members are drawn from the CCMA's social partners: organised labour, organised business and the state. The independence of the CCMA's operations from the state, any political party, trade union, employer, employer's organisation, federation of trade unions or federation of employers' organisations is legislated.

50 S 114(1) of the 1995 LRA. See also http://www.ccma.org.za/ (accessed 2017-03-05).

51 Benderman "An Analysis of the Problem of the Labour Dispute Resolution System in South Africa" 20066 AJCR 181.

52 S 112 of the 2007 LRA. The CCMA services are free of charge, which means that employees incur no costs in order to obtain assistance from the CCMA.

53 Grogan Labour Litigation and Dispute Resolution (2014) 1.

$54 \mathrm{~S} 1$ of the 1995 LRA.

$55 \mathrm{~S} 115(1)(\mathrm{a})$ to (d) of the LRA. The CCMA additionally derives its mandate from specific provisions of the Employment Equity Act 55 of 1998, (as amended). Generally, Chapter 2 of the aforementioned Act prohibits unfair discrimination, and in particular, s10(5)(6)(a) and (b) of the EEA identifies the functions that the CCMA is to perform Conciliate any dispute referred to it in terms of this Act and arbitrate disputes that remain unresolved after conciliation according to the stipulations of this Act. The CCMA also derives its mandate from specific provisions of the Basic Conditions of Employment Act 75 of 1997 as amended (BCEA). Chapter 5 of the BCEA, section 41 in particular, indicates the functions that the CCMA is to perform conciliate any dispute relating to severance pay referred to it in terms of this Act and arbitrate disputes that remain unresolved after conciliation according to the stipulations of this Act. See also the CCMA Annual Report 2015/2016 18.

$56 \mathrm{~S} 115$ of the 1995 LRA regulates how the CCMA should perform its functions. See also Grogan Workplace Law (2009) 427. Beside conciliation and arbitration, the CCMA may perform various other functions in terms of the 1995 LRA but those are beyond the scope of this study. For instance in terms of s 135(3)(c) of the 1995 LRA, the CCMA may provide advisory services to parties in dispute regarding the appropriate procedures to be followed 
memorandum released with the draft bill of the LRA highlighted that the previous dispute resolution processes resulted in only $20 \%$ of disputes being settled. The failure of the statutory structure to resolve those disputes effectively resulted in an excessively high workload for the Industrial Court and the unnecessarily high incidence of strikes and lockouts. Notably, the efficiency of a dispute resolution system relates to the success or settlement rates. In other words, total disputes referred versus total disputes resolved. ${ }^{57}$ Since its inception, the CCMA has enjoyed a national settlement rate of $70 \%$ and greater; a clear signal that the CCMA is committed to restoring sound labour and industrial relations within the South African economy. ${ }^{58}$ It is estimated that some 72 per cent of the employed in South Africa falls under the jurisdiction of the CCMA. ${ }^{59} \mathrm{~A}$ total of one hundred and seventy-nine thousand five hundred and twenty-eight $(179528)$ referrals were received by the CCMA during the 2015/2016 annual report. ${ }^{60}$ According to the $2015 / 2016$ annual report, the actual number of cases settled increased by $4 \%$. Currently the final settlement rate stands at $74 \%$ for the $2015 / 2016$ financial year.

In addition to the CCMA and statutory councils, for the purpose of maintaining an effective system of labour dispute resolution, the 1995 LRA established specialised Labour Courts with exclusive jurisdiction in labour law matters. The 1995 LRA established this court as a court of law and equity $^{62}$ with its powers and functions set out in section 158 of the 1995 LRA. By the same token, the 1995 LRA also establishes a Labour Appeal Court as a court of law and equity, with jurisdiction in all the provinces of the Republic. $^{63}$ It is a final court of appeal in respect of matters within its exclusive jurisdiction, equal to that which the Supreme Court of Appeal ${ }^{64}$ has in relation to matters under its jurisdiction, particularly in respect of all judgments and orders made by the Labour Court.

in the process of resolving labour disputes. Also, the 1995 LRA also provides for the accreditation of private agencies for the purpose of resolving labour disputes. For this reason, s 127 of the 1995 LRA confers the CCMA additional statutory powers to accredit bargaining councils for the purposes of conducting conciliations and arbitration within their sector and area as required under s 51 of the 1995 LRA.

57 Grogan Workplace Law (2007) 437.

58 See http://www.ccma.org.za/About-Us/Our-History (accessed 2017-03-05).

59 Van Niekerk, Christianson, McGregor, Smit, Van Eck Law at Work (2012) 75.

60 See the CCMA Annual Report 2015/2016 18.

61 See the CCMA Annual Report 2015/2016 31 www.ccma.org.za (accessed 2017-04-17).

62 The anomaly that the Labour Court was a court of law and the Labour Appeal Court as including equitable jurisdiction was removed by s 151(1) inserted by s11 of Act 127 of 1998 .

63 S 167 of the LRA.

64 The SCA of South Africa is the successor to the Appellate Division, which was first established in 1910 when the Union of South Africa was created. The name of the court was changed on the adoption of the Constitution in 1996. In terms of the Constitution, SCA may decide any matter, except certain labour and competition matters. But is purely an appeal court, and it may decide only appeals and issues connected with appeals. Further, the SCA may make an order concerning the constitutional validity of an Act of Parliament, a provincial Act or any conduct of the President, but an order of constitutional invalidity has no force unless it is confirmed by the Constitutional Court. 


\section{Referral timeframe}

Placing limits on referral timeframes are important stimuli for resolving disputes and ensuring that disputes are resolved in an expeditious manner. A system that is slow and that takes a protracted time to produce a resolution is ineffective. This study found that there are practical differences between referral timeframes for labour disputes under the 2007 LRA as well as the 2007 Employment Act of Kenya when compared to the 1995 LRA of South Africa. Both the 2007 LRA and the 2007 Employment Act require that labour disputes concerning alleged dismissal or termination of an employee must be referred to the Cabinet Secretary within 90 days of the dismissal or any longer period that the Cabinet Secretary, on good cause, permits. ${ }^{65}$ By the same token, the 2007 LRA requires disputes relating to the redundancy of one or more employees be referred to the Cabinet Secretary at "any stage" after the employer has given notice of its intention to terminate the employment of any employee on grounds of redundancy. ${ }^{66}$ In contrast, in terms of the 1995 LRA, dismissal disputes must be referred within 30 days to the CCMA, while unfair labour practice and discrimination disputes must be referred to the CCMA within six months of the dispute arising.

This article opines that in practice, referral of disputes regarding the alleged dismissal of an employee is the most referred labour dispute resolutions in both the Kenyan and South African systems. ${ }^{67}$ Unlike the 1995 LRA, which requires that the referral of dismissal disputes be referred to the CCMA or Bargaining Council within 30 days, this article submits that the Kenyan system of requiring dismissal disputes be referred to the Cabinet Secretary within 90 days does not portray a system keen and devoted to resolving dismissal disputes quickly. Likewise, by expressly allowing disputes relating to the redundancy of one or more employees to be referred to the Cabinet Secretary at "any stage" does not reflect an intention of a system that seeks to expedite and finalise the resolution of disputes. Therefore, consistent with the spirit of Article 159 of the Constitution of Kenya, this article recommends that the protracted referral timeframes be amended accordingly to indicate shorter referral. Otherwise, allowing such a protracted referral timeframe does not only violate the provisions of the Constitution, ${ }^{68}$ it also infringes on one of the primary purposes of the 2007 LRA of promoting an expeditious dispute settlement. ${ }^{69}$

65 S 62(3)(a) and (b) of the 2007 LRA. See also s 47(1) of the Employment Act which also declares that where an employee has been summarily dismissed or his employer has unfairly terminated his employment without justification, the employee may, within three months of the date of dismissal, present a complaint to a labour officer and the complaint shall be dealt with as a complaint lodged under $\mathrm{s} 71$.

66 S 62 (4) of the 2007 LRA.

67 CCMA 2015/2016 Annual Report http://www.ccma.org.za/About-Us/Reports-Plans/AnnualReports. See also Maema Current Trends in Employment Disputes in Kenya: A Disturbing Trajectory Paper presented, Strathmore Law School (14th September 2016); SBI International Holdings Ag (Kenya) v Amos Hadar [2015] eKLR.

68 Article $50(2)(e)$ of the Kenyan Constitution requires trial to conclude without unreasonable delay.

69 See the Preamble of the 2007 LRA. 
Surprisingly, this article found that the 2007 Employment Act seems to only regulate referral timeframes for alleged unfair dismissals. Both Article 27 of the Constitution and section 5 of the 2007 Employment Act prohibit direct or indirect discrimination based on various listed grounds. ${ }^{70}$ However, the 2007 Employment Act is silent on referral timeframes for discrimination disputes. ${ }^{71}$ This omission creates uncertainty and leaves parties in dispute wondering what the silence implies. Does the silence mean that the aforesaid disputes may be referred to the Labour Officer at any time? Should parties in dispute assume the silence in this Act to mean all the disputes should be referred within three months like dismissal disputes, or 30 days, at any time or what? This lacuna affects the effective resolution of disputes. To clear this uncertainty, it is vital that the relevant provisions of the 2007 Employment Act be amended accordingly to expressly provide referral timeframes for all disputes it seeks to regulate under its dispute resolution framework. Otherwise, one can only envision inevitable confusions in practice coupled with major uncertainty.

\section{Appointment of a conciliator or conciliation committee: A comparison with the practice in the CCMA of South Africa}

The 2007 LRA, the 2007 Employment Act as well as the 1995 LRA require that a conciliator, Labour Officer or commissioner be appointed to try and assist the parties through conciliation to reach an amicable settlement. ${ }^{72}$ Under the 1995 LRA dispute resolution system, the CCMA may only decline to appoint a commissioner if it lacks jurisdiction to conciliate the dispute referred to it. $^{73}$ On the contrary, under the 2007 LRA, there are no

70 In Koki Muia v Samsung Electronics East Africa Limited [2015] eKLR, the court found the dismissal of the claimant to be unfair and unlawful in the circumstances and further that she was subjected to racial and sexual discrimination. The court awarded the claimant, among others, 12 months' salary compensation on account of sexual and racial discrimination as well as the sum of Ksh. 7,152,000 on account of unlawful termination. Similarly, in VMK $v$ Catholic University of Eastern Africa (2013) eKLR, the claimant was awarded damages of Ksh. 5 Million on account of discrimination based on her HIV positive status. It was alleged that the University had a policy that people who were HI positive could not be employed on permanent basis. The court said: "The testing of HIV status without her consent and the disclosure of her status to 3rd persons without her authority demonstrates the seriousness of the violations and the need to compensate the claimant for the hurt feelings and eventual loss of employment due to HIV status."

71 In terms of s6(2) of the Employment Act, every employer is required to have a sexual harassment policy setting out the procedure that an employee who has been subjected to sexual harassment should fill in the complaint and pursue a remedy. See also $C A S \vee C S$ Limited (2016) eKLR.

72 S 135(1) of the 1995 LRA; see also s 65(1) of the 2007 LRA.

73 See Gcaba v Minister of Safety and Security (2010) 31 ILJ 296 (CC); [2009] 12 BLLR 680 (LC) 74. Jurisdiction means the power or competence of the CCMA to hear and determine a dispute between the parties, i.e. to conciliate and arbitrate a dispute between the parties. It is trite that the CCMA is an independent juristic body in terms of Section 112 of the LRA. As such, it does not have inherent jurisdiction. Further, it does not derive its jurisdiction from common law as in a High Court, but solely from Acts of Parliament. The CCMA mainly derives its jurisdiction from the LRA but to a limited extent also from the BCEA, EEA and other statutes. The CCMA cannot, however, decide upon its own jurisdiction. In South African Rugby Players Association (SARPA); SA Rugby (Pty) Ltd v SA Rugby Players 
regulations put in place to guide the Cabinet Secretary in the process of appointing a conciliator. Therefore, it appears highly possible that the Cabinet Secretary may refuse to appoint a conciliator based on subjective opinion rather than on regulated principles. ${ }^{74}$ This article emphasises that under such circumstances, the Cabinet Secretary acts ultra vires in that he or she arrogates to himself/herself the power to interpret the provisions of the 2007 LRA, a task that is beyond his powers. It is doubtful that section $65(3)$ of the 2007 LRA permits this lawmaking function. The situation would have been different had the 2007 LRA made provision or authorised interpretation of its provisions by the Cabinet Secretary. It currently does not afford the Cabinet Secretary such powers and therefore this could lead to abuse of power, politically motivated decisions and misjudgments. Also allowing the Cabinet Secretary the discretion to appoint or not to appoint a conciliator may not only unduly defeat access to justice for aggrieved, but also create excessive barriers to an effective settlement of disputes. This article argues that history has time and again shown that limitless power in the hands of one individual in most cases means that others are suppressed or their powers curtailed. Accordingly, the article strongly submits that the discretionary powers given to the Cabinet Secretary to decide on whether or not to appoint a conciliator to resolve a labour dispute referred to him/her is a precarious arrangement. To avoid the aforesaid barriers, this article recommends that the $\mathrm{CMC}$ proposed below should urgently be established as required by the 2007 LRA to take over from the Ministerial control of labour dispute resolution.

\section{Parties' agreement to extend conciliation timeframes beyond 30 days: A need to regulate the maximum timeframe for the agreed extension}

By their nature, labour disputes must be resolved expeditiously and be brought to finality so that the parties can organise their affairs accordingly. Under both the 2007 LRA and the 1995 LRA, an appointed conciliator or commissioner must try and help the parties settle their dispute within 30 days of his or her appointment. ${ }^{75}$ However, should this period lapse before the dispute is settled, both legislations make provision for parties to agree to a further extended period. ${ }^{76}$ The effect of an agreed extension of conciliation

Union [2008] 9 BLLR 845 (LAC) 40 the LAC held that "As a general rule [the CCMA] cannot decide its own jurisdiction. I can only make a ruling for convenience. Whether it has jurisdiction or not in a particular matter is a matter to be decided by the Labour Court. This means that .... the CCMA may not grant itself jurisdiction, which it does not have. Nor may it deprive itself of jurisdiction by making a wrong finding that it lacks jurisdiction when it actually has jurisdiction. There is, however, nothing wrong with the CCMA enquiring whether it has jurisdiction in a particular matter provided it is understood that its decision on such an issue is not binding in law on the parties."

74 In terms of s 65(3) of the 2007 LRA, if the Cabinet Secretary refuses to appoint a conciliator the Cabinet Secretary shall supply the parties to the dispute with written reasons for that decision.

75 S 67(1)(a) of the 2007 LRA; see also s 125(2) of the 1995 LRA.

76 In terms of $s$ 65(1) 2007 LRA, the Cabinet Secretary must within 21 days of a trade dispute being reported appoint a conciliator to conciliate the trade dispute; see also $s 135$ of the 1995 LRA. 
is that notwithstanding the issuance of a certificate of non-resolution, the conciliator would continue with the conciliation and no further steps in the dispute resolution process such as referral to Employment and Labour Relations Court, arbitration, or Labour Court can be invoked.

This article argues that the extended period has an effect on the finality of the matter. For instance, a serious bottleneck that exists in both systems is that, once the parties have agreed to extend the period of conciliation, there is no provision in 1995 LRA and 2007 LRA as well as the 2007 Employment Act setting out the maximum period for this extension. Perhaps the law presumes that if the parties can agree to extend the period of conciliation, they would also have the capacity to agree to terminate the proceedings. This article emphasises that for the purposes of orderly and effective dispute resolution, the timeframes for the agreed extension should expressly be regulated in both countries labour legislation. This will avoid a situation where disputes are protracted for a long time, if not open-endedly. Likewise, this will promote the primary purpose of both the 1995 LRA and the 2007 LRA of a speedy disposal and finalisation of labour disputes. ${ }^{77}$ In the long run, this will reduce or mitigate case backlogs experienced by the Employment and Labour Relations Court in Kenya as well as the Labour Court in South Africa.

\section{Statutory timeframe for appointing a conciliator: A lesson for the South African labour dispute resolution system}

In both systems, a notable difference exists regarding the timeframes for appointing a conciliator. In terms of the 2007 LRA dispute resolution system, the Cabinet Secretary is obliged to appoint a conciliator within 21 days of the dispute being referred to him or her. ${ }^{78}$ Although this approach is commendable, the author submits that 21 days is a very long period just for the parties to wait for the Cabinet Secretary to make a decision whether or not to appoint a conciliator. Arguably, such a lengthy timeframe is open to abuse since it is possible that the Cabinet Secretary may sit on the dispute up until the $21^{\text {st }}$ day before making his or her decision. One can clearly envision an undue obstacle for parties seeking to resolve their dispute without delay. Besides, it is a violation of Article 48 of the Constitution, which guarantees access to justice. ${ }^{79}$ Given these points, this article recommends that perhaps a shorter timeframe for the appointment of a conciliator of about 7 days would be more reasonable for a system that seeks to

77 In terms of s1 of the 1995 LRA, one of the primary objects of the 1995 LRA is to promote the effective resolution of labour disputes. While the Preamble of the 2007 LRA declares the purpose of the 2007 LRA as the promotion of orderly and expeditious dispute settlement, conducive to social justice and economic development and for connected purposes.

78 The Cabinet Secretary is obliged to appoint a conciliator within 21 days unless the conciliation procedures in an applicable collective agreement binding on the parties to the dispute have not been exhausted or a law or collective agreement binding upon the parties prohibits negotiation on the issue in dispute.

79 Article 48 of the Kenyan Constitution states that the State shall ensure access to justice for all persons and, if any fee is required, it shall be reasonable and shall not impede access to justice. 
encourage speedy resolution of disputes consistent with the primary purpose of the 2007 LRA. Notably, unlike the 2007 LRA, it is surprising that the dispute resolution procedure under the 2007 Employment Act is silent on the maximum timeframe within which a Labour Officer must be appointed to conciliate individual disputes. Again, this silence emphasises a need to have a single comprehensive legislation governing how all labour disputes should be processed. In the meantime, this article proposes that like the 2007 LRA, the 2007 Employment Act should be amended accordingly to incorporate expressly, the maximum timeframe for appointing the Labour Officer for the purpose of conciliating the dispute.

Unlike the Kenyan system, neither the Rules of the CCMA nor the 1995 LRA in the South African labour dispute resolution system incorporate statutory provisions prescribing the maximum timeframe within which the CCMA or Bargaining Council must appoint a commissioner to attempt to resolve the dispute. Section 133(1) and section 135(1) of the 1995 LRA only make mention that "when a dispute is referred to the Commission, the Commission must appoint a commissioner to attempt to resolve the dispute through conciliation". This article finds that the omission causes unreasonable delays in the process of resolving labour disputes for the simple reason that it is possible that the CCMA may sit on the dispute without doing anything or acting on it. Accordingly, this article stresses that a statutory provision expressly indicating the maximum timeframe for appointing a commissioner, similar to the one in the 2007 LRA of Kenya should be incorporated into the 1995 LRA, albeit shorter. This will be consistent with the spirit and purpose of the 1995 LRA of promoting a speedy and effective resolution of labour disputes.

\section{LACK OF STATUTORY ARBITRATION PROCESS UNDER THE 2007 LRA AND THE 2007 EMPLOYMENT ACT}

Arbitration refers to a process whereby the parties make presentations to a mutually agreed neutral third party, known as an arbitrator, and commit themselves to abide by that arbitrator's decision as final and binding. ${ }^{80}$ Arbitration is a well-established dispute resolution process in the commercial and international disputes in Kenya. ${ }^{81}$ However, it is yet to be established firmly in the statutory labour dispute sphere, ${ }^{82}$ a situation increasingly at odds with the trend in other African countries labour dispute resolution systems, in particular, South Africa. Gakeri reasons that arbitration, as an

80 Du Toit Labour Relations Law: A Comprehensive Guide (2014) 117; see also Khan Alternative Dispute Resolution A paper presented at Chartered Institute of Arbitrators-Kenya Branch Advanced Arbitration Course, Nairobi (March 2007) 5; Kariuki "Redefining 'Arbitrability': Assessment of Articles 159 and 189(4) of the Constitution of Kenya" 20131 Alternative Dispute Resolution Journal 5.

81 Gakeri 20111 International Journal of Humanities and Social Science 219; see also Muigua Settling Disputes through Arbitration in Kenya (2012) 5; Wambugu "Kenya: Arbitration Cuts Backlog in Courts" 23 June 2008 Business Daily 2.

82 Nyakundi Development of ADR mechanisms in Kenya and the role of ADR in Labour Relations and Dispute Resolution (Unpublished master's thesis, University of Cape Town 2015) 38. 
alternative dispute resolution technique has not been embraced so far in Kenya, partly because of the manner in which it was introduced and adopted before and after independent Kenya. ${ }^{83}$ Neither courts of law, nor the legislature have actively promoted arbitration as a dispute resolution mechanism nor has the legal framework played the requisite facilitative or supportive role in arbitration.

Noteworthy is that both Kenya and South Africa have similar statutory frameworks for conciliation, there are conspicuous disparities regarding the processes and approaches that unfold if a dispute remains unresolved after a conciliation attempt. Both systems require that, should a conciliation attempt be successful, the conciliator or Labour Officer issue a written settlement agreement that is signed by both parties to the dispute. ${ }^{85}$ Thereafter, depending on the nature of the dispute, in terms of the 1995 LRA, parties in dispute may proceed to arbitration or the Labour Court or elect to go on strike. ${ }^{86}$ On the contrary, under the 2007 LRA as well as the 2007 Employment Act of Kenya, if parties do not reach a resolution or a settlement agreement after a conciliation attempt, the parties proceed to the Labour and Employment Relations Court or embark on a protected strike. ${ }^{87}$ This means that neither the 2007 LRA nor the 2007 Employment Act labour dispute resolution system, recognise an arbitration process as a subsequent process after a conciliation attempt has failed. The blatant omission in the two enabling legislations raises serious questions regarding the effectiveness of the existing statutory framework in resolving disputes without delay.

If an arbitration mechanism is to be championed and popularised in Kenya as one of the labour dispute resolutions, it is imperative that the legislature plays a more pro-active role through the institutional framework. This article's view is that the 2007 LRA should establish an institution (the CMC as envisaged) with authority to popularise and elevate the importance of settling labour disputes through arbitration and other ADR mechanisms. This would present an ideal platform for settling disputes under both legislations as they seek to provide an inexpensive, expeditious and efficient labour dispute resolution framework. When arbitration is fully embraced as an alternative solution to resolving labour disputes, the workload in the Employment and Labour Relations Court will be eased. ${ }^{88}$ Referral to the Labour and Employment Relations Court should only be resorted to once conciliation and arbitration attempts have been exhausted or only in exceptional cases such as the complexity of the dispute.

83 Gakeri 20111 International Journal of Humanities and Social Science 220.

84 Ibid.

85 S 68(1) of the 2007 LRA and CCMA Practice and Procedure Manual $7^{\text {th }}$ Edition (November 2014) 1001-1101.

86 The costs of conciliation and arbitration are covered by the CCMA, which makes these options more economically advantageous or seen as attractive bait for the social partners as opposed to pursuing a strike or lockout early in the dispute process. The cost of conciliation fee is shouldered by the parties in dispute.

87 S 73(1) and (2) of the 2007 LRA; see also s 47(3) of the 2007 Employment Act.

88 Gakeri 20111 International Journal of Humanities and Social Science 219; see also Wambugu 23 June 2008 Business Daily 2. 
This article notes that the above position differs significantly when compared to the position under the 1995 LRA of South Africa, where most disputes are referred for arbitration when a conciliation attempt has failed. According to the 2015/2016 annual report, the arbitration settlement rate target set at the beginning of $2015 / 2016$ of $50 \%$ was exceeded by $4.2 \%{ }^{89}$ The author submits that the lack of statutory arbitration provision in both enabling legislation as one of the main quasi-judicial processes is a significant impediment to a speedy and effective resolution of statutory labour disputes envisaged by the 2007 LRA. ${ }^{90}$

Section 141(5)(a) of the 1995 LRA and section 15(4) of the Employment and Labour Relations Court Act ${ }^{91}$ are comparable. Section 141(5)(a)(i) of the 1995 LRA, states that if any party to an arbitration agreement commences proceedings in the Labour Court against any other party to that agreement about any matter that the parties agreed to refer to arbitration, any party to those proceedings may ask the Court to stay those proceedings and refer the dispute to arbitration. This is mainly because the 1995 LRA requires that arbitration must resolve certain disputes, if a conciliation attempt fails unless the parties agree otherwise. Comparatively, section 15(4) of the Employment and Labour Relations Court Act states that if at any stage of the proceedings, it becomes apparent that the dispute ought to have been referred for conciliation or mediation, the Court may stay the proceedings and refer the dispute for conciliation, mediation or arbitration.

However, neither the 2007 LRA nor the 2007 Employment Act incorporates arbitration as one of the recognised mechanisms in statutory labour dispute resolution. Given this lacuna in law, an immediate question that springs to mind is, should the court stay the proceedings, where will the matter be referred to for arbitration? Besides section 75 of 2007, the LRA is very clear that the Arbitration $\mathrm{Act}^{92}$ shall not apply to any proceedings before the Employment and Labour Relations Court. Therefore, it appears that the provisions of section 15(4) of the Employment and Labour Relations Court Act are unfortunately worded. Therefore, it is incumbent on the Kenyan legislature to examine the suitability of the legal framework on statutory arbitration, formulate systematic policy on statutory arbitration and make the necessary recommendations for reforms. This means both the 2007 LRA and the 2007 Employment Act must be amended to expressly incorporate and recognise referral of disputes for arbitration as a mechanism for labour dispute resolution when a conciliation attempt has failed to settle the matter. The amendments will bring both the aforementioned legislation in conformity not only with section 15(4) of the Employment and Labour Relations Court Act but also within the spirit of Article 159 of the Constitution, which advocates for the use of arbitration in dispute settlements. Important is to realise that Article 159(2)(c) of the Constitution is phrased in compulsory terms. It provides that alternative informal forms of dispute resolution,

89 See the CCMA Annual Report 2015/2016 www.ccma.org.za (accessed 2017-03-05) 36.

90 See the Preamble of the 2007 LRA. Also, the ILO instruments, particularly Paragraph 3 of R92 of 1951 Voluntary Conciliation and Arbitration Recommendation, require labour dispute processes to be expeditious and to be completed within a given time limit as may be prescribed by national law or regulation.

91 CAP. 234B of 2014

$92 \quad 4$ of 1995. 
including arbitration, shall be promoted. This constitutional recognition seeks to ensure that everyone has access to justice in terms of Article 48 of the Constitution $^{93}$ as well as ensuring that disputes are resolved without delay and that they are administered without undue regard to procedural technicalities that bedevil the court system.

\section{ESTABLISHMENT OF THE CMC ENVISAGED UNDER SECTION 66(1)(C) OF THE 2007 LRA: A QUEST FOR AN INDEPENDENT INSTITUTION FOR DISPUTE RESOLUTION}

It is becoming increasingly common for statutory dispute resolution systems to function independently of the State even though financed by the State through the departments of labour. ${ }^{94}$ This means all employment-related disputes are referred to and dealt with by an independent statutory institution of the first instance with centralized functions of statutory conciliation, mediation and arbitration of statutory labour disputes.

Notably, in the 2013-2017 Ministry of Labour Strategic Planning, mention is made of several institutions that were established during the 2008-2012 period of the Strategic Plan to enhance labour administration as required by the 2007 LRA. They are all currently in operation. However, the CMC envisaged under section 66(1)(c) of the 2007 LRA was left out. The consequence is that a large number of disputes escalate to the Employment and Labour Relations Court following a failed conciliation attempt by either the conciliator or the Labour Officer. As a result, this court has increasingly experienced case backlog, which sometimes includes trivial matters, some of which may perhaps be avoided should the CMC be established.

This article regards the establishment of the CMC as one significant step towards resolving most of the shortcomings identified in this article. Key among them is that of relieving case backlog, creating a single impartial institution for effective dispute resolution, eliminating delays experienced by the Employment and Labour Relations Court as well as an increase of access to justice for most poor and disadvantaged employees. Similarly, this commission would significantly assist in limiting the number of trivial disputes from escalating to the Employment and Labour Relations Court for litigation. In return, this will boost the availability of judges for cases, which must be adjudicated while also focussing on its enforcement role and speedy resolution of labour disputes. For the most part, the Commission will seek to

93 This study regards the right of access to justice as one of the fundamental rights for all employees and employers alike. As such, it is worthy of fierce protection. In this context, the terms "access" and "justice" are difficult to define in succinct terms. Likewise, the expression "access to justice" may contain contradictions. This is so because access to a dispute resolution process does not necessarily apply to justice. For instance, many legal systems are plagued by high costs, delays, complexity and uncertainty. For this reason, one may well argue that this is, at best, a retardation of access to justice and, at worst, a denial of the right of access to justice. The use of conciliation, arbitration and other consensus seeking processes are advocated as the best methods of addressing these problems and securing access to justice. Arguably, it is also a solution to the crisis faced by many judicial systems.

94 Steadman Handbook on Alternative Labour Dispute Resolution (2010) 52. 
discharge its function in a less adversarial manner and as a new institutional fulcrum for voluntarism, provide effective and high-quality conciliation, mediation and additional arbitration service to employers, employees and unions when negotiations at the workplace cannot be resolved.

\section{Devolved government: An advantage for the establishment of the CMC}

The promulgation of the Constitution ushered in immense changes in the governance landscape of Kenya. Before 2010 when governance was centralized, rigidity and delays in project implementation meant political lobbying of the national government was how an area was developed. Now, the Constitution creates a decentralized system of government wherein two of the three arms of government are devolved to the newly created 47 County Governments. ${ }^{95}$ One of the primary objectives of the devolution is to ensure the dissemination of power, resources and representation from the headquarters in Nairobi down to all counties in order to meet the needs of the local people. The devolution remains the biggest achievement of the Constitution, which ushered in a new political and economic governance system. ${ }^{96}$ It is transformative and has strengthened accountability and public service delivery at local levels. The government's agenda is to deepen the implementation of devolution and strengthen governance institutions. ${ }^{97}$ For this reason, citizens get quick access to the relevant administrative bodies where they can voice pertinent issues affecting them directly. As a result, the Ministry is very likely to experience greater strain and a high rate of dispute referral.

This article proposes that the labour legislative agenda should take advantage of this significant set up to serve as the main foundation and a springboard for the establishment and devolution of the CMC to different county governments. This will ensure that labour dispute resolution services through the CMC are devolved and accessible to parties in dispute across all the counties. Notably, the population in Kenya is predominantly rural and agriculture based. For this reason, it is an opportune time for the CMC to be established and rolled out to county levels. Large agricultural and busy industrial and agricultural regions such as the Eastern, Western, Nairobi and Central counties of Kenya would benefit significantly. Equally, in the past five years, there has been an increase in a number of small businesses as well as institutions such as universities in the counties. Therefore, devolved CMC will benefit employees employed in those sectors.

\section{Strategic planning for the establishment of the proposed CMC}

Experience from South Africa's model of labour dispute resolution shows that major amendment to any country's dispute resolution system entails

95 Article 6 read with Schedule of the Constitution.

96 Finch and Musira The World Bank and Devolution in Kenya (2016) http://www.worldbank. org/en/country/kenya/overview (accessed 2017-03-05) 1.

97 http://www.worldbank.org/en/country/kenya/overview (accessed 2017-03-05). 
creating sound policy guidelines prepared in close consultation and participation with all stakeholders. Thus, for Kenya to effectively change and shift from the current government controlled system of labour dispute resolution as through the Ministry of Labour to an independent CMC, it would certainly have to create and implement sound policy guidelines prepared in close consultation with all stakeholders and involvement of the lawmaking body in Kenya. The new policy will expressly provide statements of intention that elaborate why change is necessary, the changes planned and action plans on how these changes will be introduced. ${ }^{98}$ Once finalised and endorsed, the policy document will require specific legislative interventions, new laws, soft laws or amendments to those already in place to ensure that policy intentions are realised in practice. This is a significant factor in instilling confidence in the CMC's legal framework as well as supporting and promoting the rule of law as well.

This article acknowledges that introducing a new fully effective CMC to replace the current system will not happen overnight, it will take time. The institutionalization of the CMC will require initial investment and effort to achieve credibility and acceptability. It will require extensive outreach to the various stakeholders for acceptance and endorsement. Similarly, educational effort and raising awareness to alert employers and employees of the availability of the institution's services is key for the purposes of disputes arising in the workplace. Even more, the creation and retaining good team relations with other constituents of the country's labour administration system, especially those parts that relate in some way to dispute prevention, for instance, labour inspection will be integral to its establishment.

This may seem or sound like a challenging project but when all things are considered, the benefits to a large extent out-weigh the challenges. This article foresees that a huge advantage of establishing the CMC is that it will effectively complement and provide significant support in the judicial legal system as seen with the CCMA in South Africa.

\section{Training of the proposed CMC conciliators}

The successful practice of conciliation, mediation and arbitration require a degree of skill and cannot be conducted by persons simply because they have knowledge of the law. This article submits that identifying appropriately qualified individuals to perform conciliation and possibly arbitration services at the CMC would be pivotal. Lack of training can have a detrimental effect on the public's attitude towards the proposed CMC. For instance, once a conciliator does something in the conciliation process, which results in mistrust by the parties, it would be difficult to get the parties to have a positive attitude towards the process.

Therefore, in the event that it is established, the governing body of the CMC must seek to provide full training for those it selects for its roster.

98 ILO Labour Dispute Systems: Guidelines for improved performance http://www.ilo.org/ wcmsp5/groups/public/---ed_dialogue/---dialogue/documents/publication/wcms_211468.pdf. (accessed 2016-07-17) 80. 
Included in those efforts must be an undertaking to include conciliators with proficiency in the diverse languages in which disputants may be working. Continuing education and evaluation for the institution's efforts are also essential for inclusion in its program planning. This will ensure that qualified, credible and competent conciliators provide conciliation and arbitration services, with a view to achieving the highest possible resolution rate for disputes at the conciliation stage. Owing to the CCMA's unique nature, commissioner recruitment is conducted on a project basis and includes written assessments, a three-phase shortlisting process, two sets of interviews, and a six-month training programme. The process culminates in a three-month long mentorship programme before a commissioner is placed in a hearing room.

\section{Re-designing referral procedures and case management system for the proposed CMC}

Besides establishing the CMC and creating a panel of conciliators, is the need to develop operational procedures and rules for initiating referral of labour disputes. This article observes that referral of a dispute to the CMC will logically trigger a series of events. These will include procedures for employers and employees to follow. For example, dispute referral procedures, referral timeframes, regulations for condonation and condonation application, forms and templates for notifying the other party to the dispute of the referral made to the CMC for conciliation or to arbitration, a need for all parties to arrive on a scheduled date and participate in the conciliation process, agreement to adhere to the CMC's established administrative rules and procedures, determination of jurisdiction, procedures subsequent to the outcome of conciliation or arbitration, certification of a conciliation outcome, procedures for requesting arbitration services, including forms and templates, preparing the arbitration award, enforcement of arbitration awards, grounds for review of arbitration award, timeframes within which arbitrators must issue their awards following an arbitration process and any other important operational and procedural matters.

An important role of the institution will be to provide an annual register or reports with statistics of its activities throughout the year. Therefore, a highly sophisticated electronic case management system that records all disputes referred to the CMC, their nature and their status will need to be designed. Should the register show a high progressive settlement rate of the disputes referred, it will significantly elevate the confidence of its users. Notably, the CCMA has established a monitoring and evaluation system that provides for the quarterly performance monitoring and reporting of the delivery of the new five-year Senz'umehluko strategy that commenced in the 2015/16 financial year. The system is based on principles of building a culture of accountability and continual learning, consistent with the approach adopted by the Monitoring and Evaluation Department in the Presidency. In particular, the CCMA uses a system of scorecards to monitor and evaluate the performance of the strategic plan, the Annual Performance Plan, the

99 See the CCMA Annual Report 2015/2016 www.ccma.org.za (accessed 2017-04-17) 102. 
respective Departmental Operational Plans and the Regional Operational Plans, on a quarterly and annual basis. The scorecard is designed to provide for both external reporting and internal performance management purposes. ${ }^{100}$

This article suggests that much of the foregoing could be implemented through early development of an accessible website similar to the CCMA's one setting forth a description of the process and the substantive standards, the procedures for utilizing the procedures, necessary referral forms and other helpful documents to the parties, a listing with supportive biographical material of those on the panel and evaluation materials to be used in an effort to enhance future effectiveness. Similarly, this could further be elaborated in detail in legislation and internal procedures. Kenya can learn from the CCMA's facilities for "walk-in" referrals and the simplicity of referral forms to facilitate the swift referrals of disputes.

\section{Structural framework and initial support of the proposed CMC}

Like any other new project, the CMC will initially seek to operate under the guidance and support from the government and perhaps with the cooperation of ILO for technical support. ${ }^{101}$ Likewise, interested institutions such as trade unions, non-governmental organisations, employers' organisations, manufacturer groups and perhaps consumer groups will be brought on board to participate in the efforts of the CMC. This article acknowledges that with the involvement of such a diverse cross-section of participating organisations, the development of an effective and long-lasting governing body might result in considerable problems and perhaps potential conflicts. To avoid such difficulties, it is imperative that a Governing Board, similar to the National Economic Development and Labour Council of South Africa be established by law. ${ }^{102}$ The Constitution of such a board should include the main role players such as representatives of employers, trade unions and government. Like NEDLAC, the established Governing Board will be key in handling large policy and direction issues with the administration of the operation entrusted to executive directors, seconded perhaps by a member from participating organisations. Importantly, the Governing Board's

100 See the CCMA Annual Report 2015/2016 www.ccma.org.za (accessed 2017-04-17) 20.

101 The ILO was very instrumental in the review project of the old Kenyan labour legislation that ended up to the enactment of the current labour legislation passed in 2007.

102 Hereinafter "the NEDLAC", see http://new.nedlac.org.za/ where it is recorded that at NEDLAC, Government comes together with organised business, organised labour and organised community groupings on a national level to discuss and try to reach consensus on issues of social and economic policy and to make economic decision-making more inclusive, and promote the goals of economic growth and social equity. NEDLAC is funded by the Department of Labour, and is involved with the Departments of Trade and Industry, Finance and Public Works. Organised business is represented by the formed Business Unity South Africa (BUSA), which brings together the Black Business Council (BBC), and Business South Africa (BSA). The three main labour federations in South Africa represent organised labour: COSATU, FEDUSA and NACTU. The South African Youth Council, National Women's Coalition, South African National Civics Organisation, Disabled People South Africa, Financial Sector Coalition and the National Co-operatives Association of South Africa represent organised community. 
eligibility criteria for appointment, its main functions and responsibilities will need to be clearly articulated in a policy document.

Funding for the establishment of an institution of the CMC's magnitude and its effective operational framework is understandably a challenge. It comes on the scene at a time when all the key players, particularly the national government, are already under considerable economic pressure in fulfilling numerous existing mandates. This article envisages that if established, the CMC will initially support itself from fees charged for its services. This article acknowledges, however, that this arrangement alone may not be sufficient as it could take a considerable period of time. Hence, the government may have to provide initial seed money to support the CMC's set up, its initial activities as well as early outreach phases, including training and continuing education. Understandably, this was also the case when the CCMA of South Africa was initially established. Although one can still foresee the need for subsidizing some disputants, who may lack the resources to pay their share of any fee for services provided. To date, the CCMA of South Africa offers its services to the disputants free of charge. ${ }^{103}$ Likewise, this article envisions that should the CMC be established and stabilized, it will strive to reach milestones similar to the CCMA.

\section{Representation at the proposed CMC}

Both Kenyan and South African dispute resolution systems place an absolute prohibition on legal representation at conciliation proceedings. However, in subsequent processes, the representation may be permitted.

Under the 1995 LRA model of dispute resolution, a party to the dispute may appear in person or be represented only by a director or employee if the party is an employer of that party. If it is a close corporation, a member of that close corporation, any office bearer, official or member of that party's registered trade union or registered employers' organisation. If the party is a registered trade union, any office bearer, official or member of that trade union authorised to represent that party or if the party is a registered employers' organisation, any office bearer or official of that party or a director or employee of an employer that is a member of that employers' organisation authorised to represent that party. ${ }^{105}$

Comparatively, the 2007 LRA is silent on the position regarding legal representation for collective labour disputes. It is unknown whether this silence implies that legal representation may or may not be allowed at conciliation. Despite the silence on legal representation for collective disputes under the 2007 LRA, this article establishes that with individual disputes, advocates are prohibited from representing a party in the proceedings before a Labour Officer. ${ }^{106}$ Nevertheless, such party may be an official of a trade union or an official of an employers' organisation may

103 The vision of the CCMA of South Africa is to "be the premier dispute management and dispute resolution organization", see www.ccma.org.za (accessed 2017-03-17).

104 Netherburn Engineering CC t/a Netherburn Ceramics v Mudau 200930 ILJ 1521 (CC).

105 Rule 25(1) of the Rules for the Conduct of Proceedings before the CCMA.

$106 \mathrm{~S} 48$ of the 2007 Employment Act. 
assist or represent notwithstanding the fact that the official is an advocate. Accordingly, the study recommends that the 2007 LRA should be amended to explicitly address the position regarding legal representation. The country legislative agenda may perhaps adopt similar provisions dealing with representation under the 1995 LRA and CCMA Rules to guide the proposed CMC.

\section{Independence of the proposed CMC}

The independence of any dispute resolution institution is one of the cardinal principles to an effective dispute resolution system. Taking appropriate measures to ensure that institutions mandated to resolve disputes remain independent is important and that all its members are seen to be persons of appropriate standing and moral authority. These are the same principles applicable to most, if not all judicial systems in the world. Therefore, in order to be effective and to secure the confidence of its users, guarding against jealousy of its independence will be imperative for the CMC. This entails securing its operations to avoid any undue external interference or control by political parties or employers or trade unions or the government. Currently, this is not the case under the Kenyan system. The integrity and independence of the current system of government controlled dispute resolution may severely be scrutinized.

Therefore, if established as an independent commission, the CMC will take over the responsibilities of dispute prevention and resolution from the ambit of the Ministry of Labour.

This article proposes that the one way for the CMC to guard its independence and that of its members is to appoint the members on a permanent basis and to protect their employment in the same way as civil servants in Kenya. Besides that, the other way in which the CMC may mark its independence and ultimately its moral authority to engage in the resolution of labour disputes relates to its internal structure. A good example of how this can be done is by creating senior positions for the CMC staff, similar to directors of the CCMA in South Africa, for example, a president or vice-president. These people should then be tasked with the responsibility to ensure successful operations of the CMC. In practice, this would include the allocation of disputes among the members, as well as for the performance of conciliation or arbitration in, particularly significant or complex disputes.

In the same way, in order to strengthen the independence and authority of the CMC specific qualifications are required for the more senior staff. For example, the Directors and Deputies in various CMC branches will have to be accorded a status similar to that of judges. This means that they will need the same experience and qualifications as judges to be eligible for appointment. Special expertise in labour law practice of the country should play a huge role before one is appointed. Requirements of this nature will help to invest the staff and their respective branches with certain moral authority. Importantly, it will instil public confidence in the CMC services. This article assumes that a high confidence instilled in this institution will influence the willingness to refer disputes into this institution for resolution and to equally accept the outcome of a settlement agreement. Further, 
ensuring equal representation of the social partners in the dispute resolution system is also an important element in safeguarding the independence of a system. ${ }^{107}$

\section{Need to merge individual and collective disputes resolution processes: CMC to assume the task of resolving both categories of disputes}

There is an absolute necessity to have a single system capable of dealing effectively with all statutory labour disputes in Kenya. This is an important structural imperative that will abolish the current dual system of labour disputes and will direct all labour disputes to one independent institution (the CMC) as the institution of the first instance for conciliation and perhaps to arbitration should a conciliation attempt fail. This article highly proposes that the provision of section 48 of the 2007 Employment Act and section 62 (1)(a)(b) of the 2007 LRA regulating the referral procedure be merged in order to provide a single comprehensive statutory framework as a one-stop shop tailored to resolving all labour-related disputes, both individual and collective. In theory, the labour dispute resolution system should be a linear process. The processes set out under the 2007 LRA and the 2007 Employment Act conflict one another and unnecessary duplicate processes are provided in either legislation. For instance, both the 2007 LRA and the 2007 Employment Act provide a dispute resolution framework for the same matters such as unfair dismissals in the workplace as well as procedural fairness. If the dismissal law was located in the 2007 LRA, this would minimise if not eliminate the scope for litigants shopping for a forum between the 2007 Employment Act and the Employment and Labour Relations Court. ${ }^{108}$ For this reason, a single authoritative source of information is desirable.

It is unnecessary to have two enabling pieces of legislation regulating the process of labour dispute resolution of the same nature of disputes. Having a single balanced legislation that provides a single entry point and clear channel for resolving statutory labour disputes is vital in ensuring effectiveness. This statutory re-arrangement will serve to avoid the fragmentation of statutory labour dispute resolution systems as well as help in eradicating the inconsistency, unnecessary complexity, duplication of resources and jurisdictional confusion caused by the multiplicity of laws. Importantly, it will eradicate inequality of treatment of workers arising from the application of differential laws and standards by conciliators. In addition, such a re-arrangement will strongly reinforce and boost access for all employees as of the right to an external dispute resolution.

107 This is what paragraph 2 of Recommendation No. 92 envisaged.

108 Currently, s 47(1) of the 2007 Employment Act states, "Where an employee has been summarily dismissed or his employer has unfairly terminated his employment without justification, the employee may, within three months of the date of dismissal, present a complaint to a labour officer. In terms of subsection (3), the right of the employee to present a complaint under sub-section (1) shall be in addition to his right to complain to the Employment and Labour Relations Court on the same issue." 
The Legislature carefully designed the 2007 LRA and the 2007 Employment Act so that each gives effect to particular labour practices. A closer inspection of both the 2007 LRA and the 2007 Employment Act reveals substantively that the two statutes regulate discreet issues. Arguably, the legislature intended to carefully demarcate the 2007 LRA as the statute regulating collective bargaining, dismissal and unfair labour practices. While the 2007 Employment Act was enacted to establish, enforce and regulate basic conditions of employment, such as leave and hours of work. This is evident from the Preamble of both the aforementioned legislation. ${ }^{109}$ Nothing is said in the Preamble to the 2007 Employment Act or elsewhere in the provisions of the 2007 Employment Act that one of its purposes is to enhance effective dispute resolution. Therefore, requiring that individual disputes be referred to the Labour Officer seems to create dual forums for dispute resolution and resuscitate the problems identified above under the old labour laws.

Otherwise, the current dual system of labour dispute resolution creates an impression that the 2007 LRA is actually a "Unions Labour Relations Act" and the 2007 Employment Act is an "Individual or non-unionised Employee Act". Besides, notwithstanding domestic law and practice, the importance of designing a monistic system of labour dispute resolution capable of settling both individual and collective disputes expeditiously must be stressed.

\section{Establishment of councils similar to the ones under the South African system to complement the CMC functions in various sectors and industries}

Subsequent to the establishment of the $\mathrm{CMC}$, this article recommends that provisions should be made in the enabling legislation for the development of bargaining councils at industrial and or sectorial level. Should they be established, it would be important that their composition be comprised of tripartite representatives of employers, government and employees. This article proposes that mandatory provisions will have to be incorporated in the enabling legislation requiring accreditation of these councils by the CMC before they can perform their dispute resolution functions. In other words, arrangements will have to be put in place for a system of accreditation of such bargaining units, with a view to enabling them to provide the same range of services as the $\mathrm{CMC}$ in their designated industry or sector as prescribed by the CMC itself. Like the position in South Africa, the bargaining council would need to develop a Constitution in accordance with which their function would be regulated. Section 27 of the 1995 LRA provides for the establishment of a bargaining council. ${ }^{110}$

109 The Preamble of the 2007 Employment Act expressly states "[A]n Act of Parliament to repeal the Employment Act, declare and define the fundamental rights of employees, to provide basic conditions of employment of employees, to regulate employment of children, and to provide for matters connected with the foregoing." While the Preamble of the 2007 LRA states that, "an Act of Parliament to consolidate the law relating to trade unions and trade disputes ... the encouragement of effective collective bargaining and promotion of orderly and expeditious dispute settlement".

110 In Photo Circuit SA Ltd v De Klerk No (1991) 12 IU 289 (A) 145 the court held that the bargaining council has jurisdiction only over employers and employees in the sector and 


\section{Above all Prevention, Prevention, Prevention: Dispute Prevention Functions of the Proposed CMC}

One of the goals of "proportionate dispute resolution" is to increase advice and assistance to help people resolve their disputes earlier and more effectively. ${ }^{111}$ This article submits that establishing the CMC and councils alone will of course not overcome all of the existing problems and challenges facing the dispute resolution system in Kenya. Above and beyond, establishing specialised labour dispute resolution institutions is an urgent need to give sufficient attention to dispute prevention. This article emphasises that the most instructive way to evaluate labour dispute resolution mechanisms is to see them as ongoing experiments in dispute prevention, management and resolution. As pointed out earlier, disagreement and conflict are considered normal in an economy in which market forces dominate the resource allocation process. However, this does not mean that such disagreements, complaints and conflicts must escalate into major labour disputes. Creating institutional structures and making necessary arrangements where disagreements are resolved peacefully, quickly, and fairly, will prevent minor complaints escalating into disputes and more often resulting in violent and disruptive strikes. Alongside the lack of effective dispute resolution conciliation institutions, this article observes that in Kenya, a large number of employees are employed in informal sectors and their employers lack the required knowledge and understanding of their respective rights and obligations under the law. Likewise, employees have little knowledge of their rights and available dispute resolution channels where they can refer their labour disputes should they want to vent unfair treatment by their employers.

\section{MAGISTRATES PRESIDING OVER EMPLOYMENT AND LABOUR RELATIONS DISPUTES}

The South African system of labour dispute resolution, by definition, provides scope for expertise in labour law and labour relations. In Kenya, the appointment of conciliators is not necessarily linked to expertise in labour law and labour relations. As a result, the Chief Justice may, by notice in the Government Gazette, appoint certain Magistrates to preside over cases involving employment and labour relations in respect of any area of the country. ${ }^{12}$ This means such Magistrates are then given jurisdiction and authority to handle disputes relating to employment and labour relations in addition to any other disputes as may be designated in a Gazette notice by the Chief Justice on the advice of the Principal Judge.

This article emphasises that such an arrangement potentially hinders the achievement of the primary purpose of the Employment and Labour Relations Act, which is to resolve labour disputes expeditiously. For one,

industry for which it is registered and its agreements binds only parties to such an agreement.

111 Steadman Handbook on Alternative Labour Dispute Resolution 49.

112 16(2) of the Labour Institutions Act, 2007; see also the GN in GG 9243 of 27 July 2011.

113 S 29 of the Employment and Labour Relations Court Act, 2014. 
most Magistrates are not trained purely to deal with labour disputes and so do the Magistrate Court's jurisdiction. They are used to putting on a decision making and adjudication cap and tend to have difficulties switching to a labour law cap, which primarily requires patiently watching a noninterventionist process unfold. Besides, Magistrates are already grossly overloaded and therefore, delays may be experienced given the enormous case backlog already experienced in their own civil matters. This article recommends that the task of resolving labour disputes should be reserved for specialists in labour law. Meaning again that the CMC should urgently be established and labour specialists or experts be appointed to deal purely with labour disputes.

\section{CONCLUSION}

In this article, the Kenyan statutory labour dispute resolution system has been compared with the South African system. As shown, the two countries' dispute resolution systems depict noticeable similarities and marked differences. The South African labour dispute system is much more developed than the Kenya system, so there are a lot of lessons that Kenya can learn from the South African system. The article illuminated some of the salient weaknesses of the 2007 LRA as well as the 2007 Employment Act. Some of these include protracted referral timeframes for dismissal disputes, non-regulation of the maximum timeframe, where parties have agreed to extend conciliation attempts beyond a 30-day period, lack of a regulated timeframe for appointing a conciliator/ commissioner to conciliate the dispute, lack of statutory framework for an arbitration process under the 2007 LRA and the 2007 Employment Act and an unnecessary dual system of labour dispute resolution, which, besides wasting resources, causes confusion and inconsistencies in decision making. Above all is that the Kenyan system lacks an independent statutory institution similar to the CCMA of South Africa with a primary function of resolving labour disputes. This is despite the 2007 LRA requiring the establishment of the CMC. The responsibility of resolving statutory labour disputes is thus still heavily under the control of the government through the Ministry of Labour. This arrangement remains a major obstacle to the effective resolution of labour disputes, particularly due to lack of impartiality, integrity and fairness in the process and outcome of the decisions made. The consequence is the increase in strikes, lockouts and other related labour disputes.

This article does not claim to have exhausted all the problems in both countries' labour dispute resolution systems. It must be remembered that this article was particularly undertaken from a legal theoretical and practical perspective. For that reason, supplementary research may be necessary as both systems continue to develop. In addition, since both the 2007 LRA and the 1995 LRA of South Africa exclude the application of the Arbitration Act, the scope of this article was only limited to labour dispute resolution systems under the 1995 LRA, 2007 LRA and the 2007 Employment Act.

This state of affairs contrasts with the position in South Africa and the explanation for this difference is not hard to find. The informal dispute resolution through CCMA and accredited bargaining councils in South Africa has proven very reliable, accessible to all and dispensing justice timeously in 
employment disputes. The establishment of the CCMA has helped to reduce the number of cases that would have been referred to the formal courts. Therefore, this article strongly recommends that the current government controlled model of the labour dispute resolution system should be abolished and a transitional framework urgently be put in place to direct labour disputes away from the ambit of the Cabinet Secretary and Labour Officers. Otherwise limiting referrals and conciliation processes to the hands of the Cabinet Secretary and Labour Officer, Kenya subjects labour dispute resolution processes to all the defects inherent in a government controlled process.

In the end, whether the Kenyan government will take action and introduce these salient changes is yet unknown. Given the historical context of the passage of these laws, it is a decade now since the current labour legislation was enacted. For this reason, it is only reasonable that they should be relooked at afresh within a sober atmosphere to come up with one balanced legislation that seeks to provide one clear procedure for resolving statutory. This article makes the above recommendations, which, if put into effect, will contribute significantly not only in treating the symptoms, but also the source of conflicts in the workplace. All things considered, this article strongly recommends that the establishment of the CMC envisaged in the 2007 LRA is timely and worthy of more support. Its establishment will lead to effective, relatively informal, less legalistic, and expeditious resolution of labour disputes than court adjudication. 